
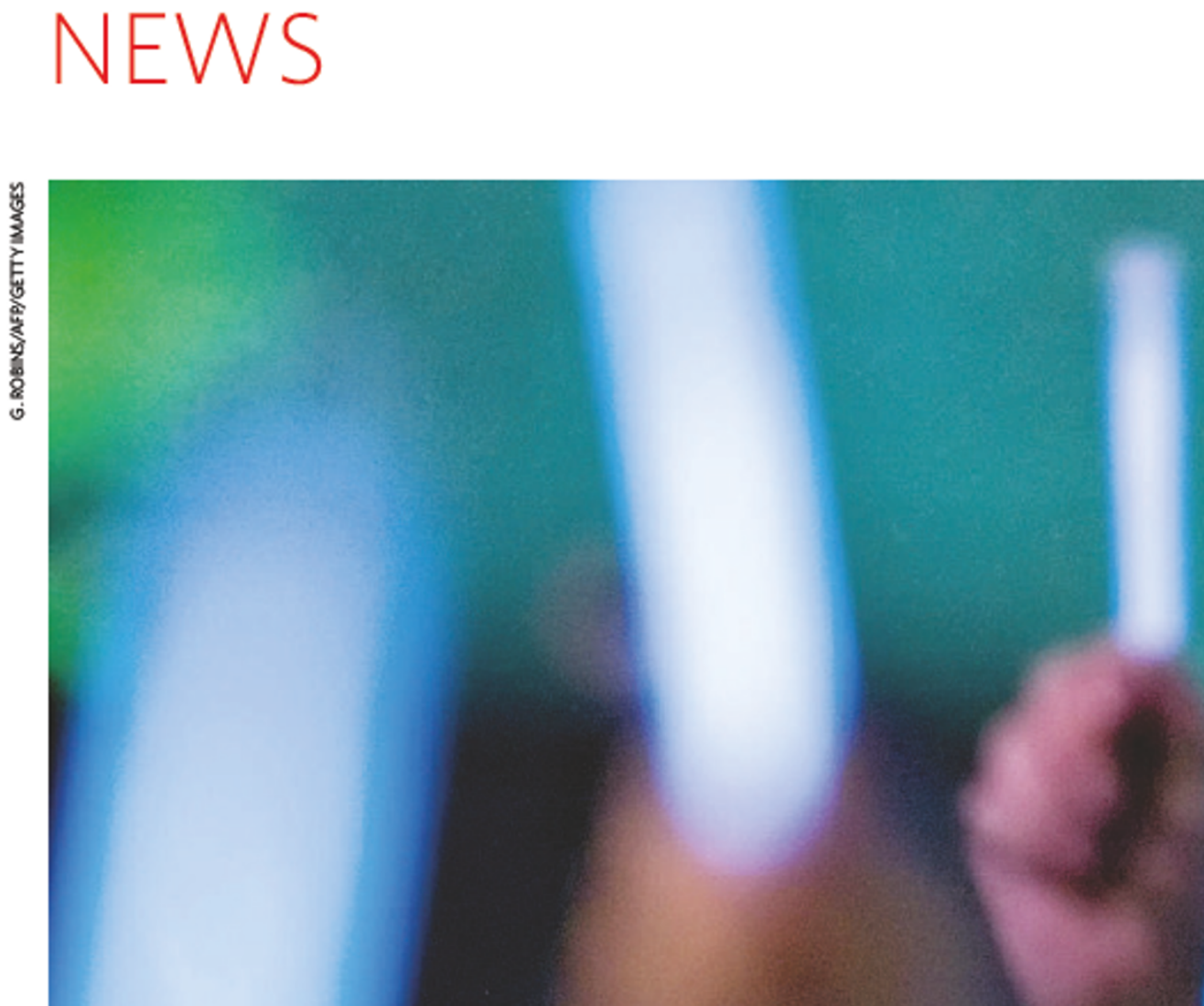

\title{
Light shed on battle against HIV
}

\section{TORONTO}

Why does the human body fail to defend itself from the virus that causes AIDS? The answer, researchers are finding, could be that HIV triggers a natural mechanism that impairs the main cells responsible for fighting the virus.

As a result, these cells, called killer T cells, eventually become exhausted and give up their fight. Now, research indicates that giving these tired cells a boost may be simple, and clinical trials using this strategy could start as early as next year.

"This is really a very important phenomenon, and it explains a lot of things," says RafickPierre Sékaly of the University of Montreal in Quebec, senior author of one of two papers published on 20 August. "We would like to be able to push this into patients and show whether this has an effect.

\section{Clue in mice}

The story began last December, when Rafi Ahmed of Emory University in Atlanta, Georgia, reported work on mice infected with a chronic viral infection ${ }^{1}$. His group studied the $\mathrm{T}$ cells these mice made to target the longterm infection. The researchers found that the cells expressed much higher levels of a protein called PD-1 than mice infected with a shortterm infection. This was intriguing, because scientists already knew that PD-1 can act as a brake on $\mathrm{T}$ cells that express it, forcing them to shut down their fight against infections.

Even more tantalizing was Ahmed's finding that he could release the PD-1 brake by injecting the mice with a molecule to block PD-1's interaction with another protein, called PD-1 ligand. That protein triggers the PD-1 molecule to shut off T cells. Stopping the deadly interaction between PD-1 and PD-1 ligand seems to release the restraint on $\mathrm{T}$ cells, Ahmed reported.

Researchers then raced to examine PD-1 in people. Teams included one led by Sékaly, now reporting results in Nature Medicine ${ }^{2}$, and another led by Bruce Walker of Massachusetts General Hospital in Boston, who reports results in Nature ${ }^{3}$.

Both teams found that, in human patients, the $\mathrm{T}$ cells that should be fighting off HIV express very high levels of PD-1. Both papers also show that levels of PD-1 expression correlate with the amount of HIV a patient has in his or her body, indicating that the protein has something to do with how well the patient controls the virus. And both papers report that interfering with the partnership between PD-1 and PD-1 ligand can rejuvenate the cells' fight against the virus.

${ }^{\alpha}$ Exhaustion has been a proposed mechanism of T-cell failure in HIV disease for a long time," says Michael Lederman, an immunologist at Case Western Reserve University in Cleveland, Ohio, who was not involved in the work. "What seems nice about this piece is that it explains some observations that have been made for some time, and it may apply to other infections. And there's an ability to intervene."

\section{Future trials}

At least one company is already looking at ways to use the finding. Medarex, based in Princeton, New Jersey, is testing a protein that interferes with the PD-1/PD-1 ligand partnership. The company is interested in it as an anticancer agent at the moment, but is also talking to HIV researchers about potential dinical trials.

\section{"This work is elegant, The finding could also help} carefully done and illuminate other chronic viral solid - but we've got diseases, such as hepatitis C. to And it could help scientists unravel another interesting story: how certain people infected with HIV can control their infections naturally, without drugs, and almost never get sick with AIDS.

On 16 August, Walker and Sékaly announced that they are beginning the first large-scale study on the genetic make-up of these people, known as 'élite controllers'. Sékaly adds that 
